\title{
Electrochemical Analysis of the Redox State of Silver Contained in Antibacterial Material
}

\author{
Yoshihiro Inoue $^{1}$, Hajime Hamashima ${ }^{2}$ \\ ${ }^{1}$ Department of Microbiology, Showa Pharmaceutical University, Machida, Japan; ${ }^{2}$ Laboratory of Bio-Medicinal Pharmacology, \\ Showa Pharmaceutical University, Machida, Japan. \\ Email: inoue@ac.shoyaku.ac.jp
}

Received January $13^{\text {th }}, 2012$; revised February $26^{\text {th }}, 2012$; accepted March $12^{\text {th }}, 2012$

\begin{abstract}
Introduction of silver into some inorganic material causes the resulting mixture to have antibacterial activity. Here, we investigated the role of silver in the bactericidal activity of silver-loaded zeolite, by measuring the effects of silverloaded zeolite on Escherichia coli cell viability under conditions in which the oxidation state of the silver was controlled electrochemically. Bactericidal activity was observed when the sweeping voltage between 0 and $0.7 \mathrm{~V}$ was applied to the silver electrode. When nitrogen gas bubbling or reactive oxygen scavengers were added to the experimental system, bactericidal activity decreased. These results indicated that the redox cycle, $\mathrm{Ag}^{0}<\longrightarrow \mathrm{Ag}^{+}$, caused the dissolved oxygen to form reactive oxygen species.
\end{abstract}

Keywords: Silver; Antibacterial Activity; Electrochemical Analysis

\section{Introduction}

Sterilization is an important process for sanitation and hygiene. Inorganic antibacterial materials have been attractive as antibacterial agents and are used various situation [1-4]. Of the many inorganic antibacterial materials, silver-loaded materials are particularly attractive because they are highly effective antibacterial agents [5-7].

We previously prepared a silver-loaded material using zeolite (crystalline aluminosilicate) and confirmed that silver-loaded zeolite (Ag-Z) in deionized water has antibacterial activity [8]. We used zeolite as a carrier to load silver ion. Zeolite has exchangeable cation site. It enables to make the material with high dispersion of silver. Ag-Z in water causes dissolved dioxygen to form reactive oxygen species. We also reported that light irradiation was necessary to form reactive oxygen species [9].

The aim of this was study to examine the role of silver in $\mathrm{Ag}-\mathrm{Z}$ on activating dissolved oxygen. We focused on the redox status of silver in this study because it was a factor in the reduction of dissolved dioxygen. Reactive oxygen species were formed by serial reduction of dissolved oxygen in Ag-Z. The oxidation number might vary during the antibacterial process. To investigate the contribution of the redox state of silver in Ag-Z to the bactericidal activity of this compound, bactericidal assays were performed under conditions in which the redox state of silver was controlled using an electrochemical method. Electrochemical method was used for the pre- cise control of the state of silver.

The present results may contribute to the creation of more effective antibacterial materials.

\section{Materials and Methods}

The water used in this study was deionized water $(>17$ $\mathrm{M} \Omega \cdot \mathrm{cm}$ ) prepared using a puric system, specifically the puric-S model (Organo Co. Ltd., Japan). The strain Escherichia coli NIHJ JC2 was used in the assays of bactericidal activity.

A suspension $(300 \mathrm{ml})$ containing E. coli (c.a. $10^{7}$ $\mathrm{cfu} \cdot \mathrm{ml}^{-1}$ ) was stirred using a magnetic stirrer. The start of the treatment was the time point at which the voltage was applied. A dual potentio-galvanostat (DPGS-1, Nikko Keisoku, Japan) and a potential sweeper (NPS-2, Nikko Keisoku, Japan) were used to control the oxidative state of the silver. The silver electrode, saturated silver chloride electrode and platinum electrode were used as the working, referential, and counter electrodes, respectively. The sweeping speed was $20 \mathrm{sec} \cdot \mathrm{V}^{-1}$.

To prepare the bacterial suspension, sodium nitrate solution was used for avoiding the precipitation of silver salt during the electrochemical process. The concentration was determined to be $0.5 \mathrm{~mol} \cdot \mathrm{l}^{-1}$ by considering the osmotic pressure. The antibacterial activity was estimated by taking the time course of the viable cell count of $E$. coli NIHJ JC2 cells.

The viable cell counts were determined by colony- 
counting. Samples were removed for determination of viable cell counts. Serial 10 -fold dilution of the bacterial suspension $\left(10^{-1}-10^{-4}\right)$ were then prepared in phosphate buffered saline (PBS; pH 7.0). Aliquots of $100 \mu$ l of the diluted sample were plated on agar-solidified Mueller Hinton broth (Difco, Detroit, MI). The plates were then incubated at $37^{\circ} \mathrm{C}$ for $24 \mathrm{~h}$ and then colonies were counted. Killing curves were constructed by plotting numbers of viable cells against time. All assays were performed in triplicate and averaged values were plotted.

\section{Results and Discussion}

Light is necessary to elicit the antibacterial activity of Ag-Z [9]. We focused on the oxidation state of silver in this study because light irradiation may lead to the reduction of silver ions in systems containing Ag-Z. According to the potential-equilibrium diagram for the silver-water system, the oxidation state of silver changes at around $0.7 \mathrm{~V}$ when $\mathrm{pH}$ of the system is 5.2.

An electrolyte solution was used to keep the bacterial cells in suspension during the electrochemical analysis. Nitrate was used as the solute because the salts in some other buffer solutions react with silver ions to form precipitates. The oxidation number of silver in Ag-Z must be +1 since silver introduced to zeolite using silver nitrate solution by ion-exchange reaction. The change in the viable cell count of $E$. coli cells was determined when the applied voltage was fixed at $0.6 \mathrm{~V}$. Under these conditions, the viable cell count did not change substantially over the course of $60 \mathrm{~min}$ (Figure 1). Moreover, the viable cell count did not change substantially for $60 \mathrm{~min}$ when silver metal ( $1 \mathrm{~g})$ was added to the bacterial suspension (data not shown). These results indicated that $\mathrm{Ag}-\mathrm{Z}$ had very little bactericidal activity when the oxidation number of silver was equal to zero.

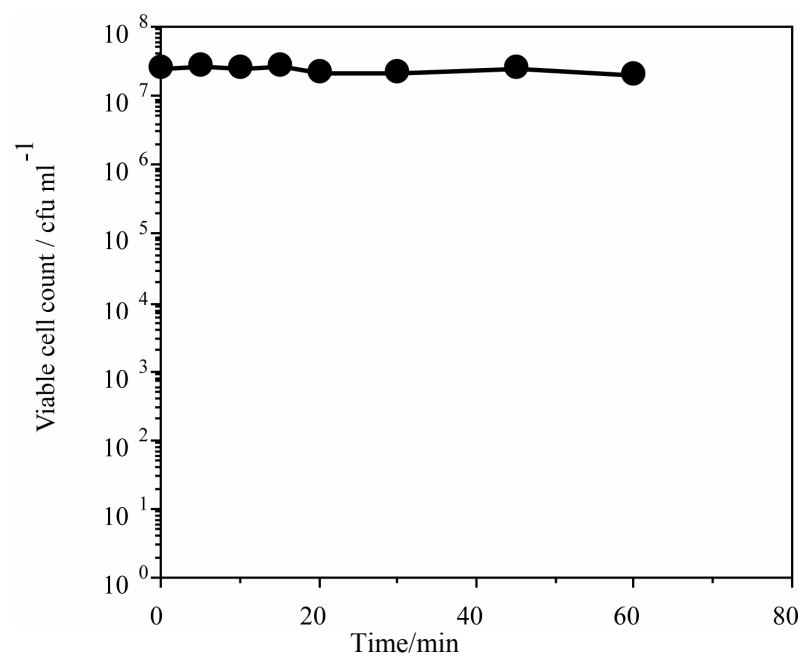

Figure 1. The bactericidal activity of the silver electrode when $0.6 \mathrm{~V}$ were applied to the system.
The cyclic voltammogram analysis at the silver electrode in a $0.5 \mathrm{~mol} \mathrm{dm}^{-3}$ sodium nitrate solution showed that the oxidation process, $\mathrm{Ag}^{0} \longrightarrow \mathrm{Ag}^{+}$, occurred at ca. $0.62 \mathrm{~V}$ (data not shown). To assess whether the silver redox process, $\mathrm{Ag}^{0} \longrightarrow \longrightarrow \mathrm{Ag}^{+}$, affected the bactericidal activity of $\mathrm{Ag}-\mathrm{Z}$, the change in the viable cell count was determined while a sweeping voltage, between 0 and 0.7 $\mathrm{V}$, was applied to the system. (Figure 2) The number of viable $E$. coli cell decreased drastically during the $5 \mathrm{~min}$ to $15 \mathrm{~min}$ period, and no viable cells was found at $20 \mathrm{~min}$. This result indicated that the cycle of oxidation-reduction, $\mathrm{Ag}^{0}<\longrightarrow \mathrm{Ag}^{+}$, affected the bactericidal activity of Ag-Z.

These results indicated that the increase in bactericidal activity of $\mathrm{Ag}-\mathrm{Z}$ was not simply the result of the reduction of silver, but rather that $\mathrm{Ag}-\mathrm{Z}$ acquired bactericidal activity as a result of the $\mathrm{Ag}$ redox cycle. Figure 2 shows the effect of nitrogen gas bubbling on the bactericidal activity of Ag-Z during the silver redox cycle. Although the silver redox cycle proceeded under these conditions, the number of viable cells barely changed over the course of 60 min when nitrogen gas was bubbled into the system. The bubbling of nitrogen gas purged the dissolved dioxygen out of the system. Therefore, the redox process of silver affected the activation of the dissolved dioxygen.

In this system, the oxidation of silver metal may cause oxygen to be reduced, and the super oxide anion $\left(\mathrm{O}_{2}^{-}\right)$ is the most likely chemical species to be formed in this process. To investigate this possibility, we monitored the production of the super oxide anion using cytochrome $\mathrm{c}$ (Figure 3). The adsorption of the solution at $550 \mathrm{~nm}$ was observed as the electrochemical cyclic redox reaction of silver proceeded. This analysis confirmed that the re-

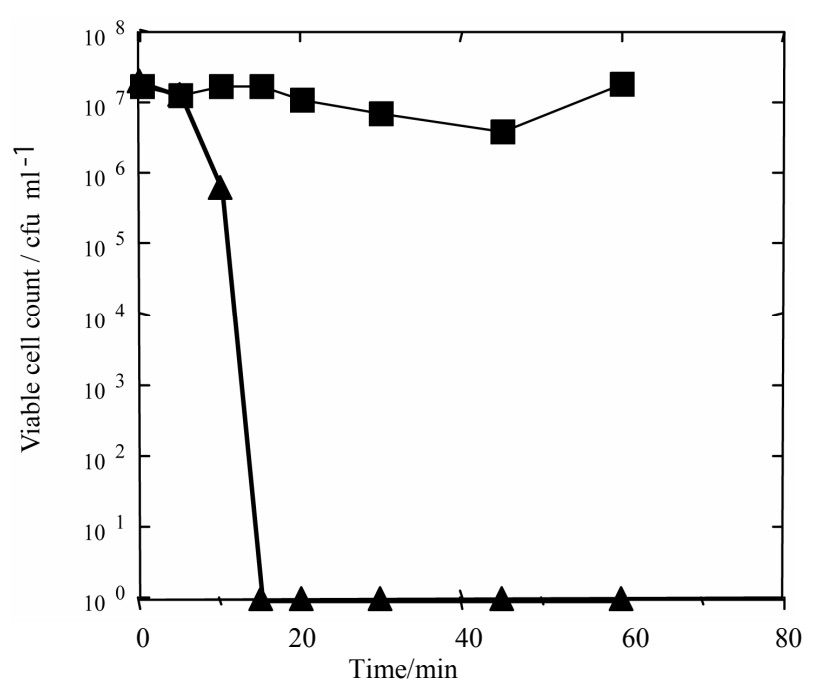

Figure 2. Effect of the sweeping of the applied voltage and nitrogen gas bubbling on the bactericidal activity of the silver electrode; $\boldsymbol{\Delta}$ : the applied voltage was swept between 0 and $0.7 \mathrm{~V}$ without N2-bubbling; $\square$ : the applied voltage was swept between 0 and $0.7 \mathrm{~V}$ with N2-bubbling. 
ducetion of oxygen was occurring as the oxidation of silver occurred.

Figures 4 and 5 show the effect of catalase and benzoate $\left(0.1 \mathrm{~mol} \cdot \mathrm{dm}^{-3}\right)$ on the bactericidal activity of $\mathrm{Ag}-\mathrm{Z}$ as the silver redox proceeded. Catalase and benzoate are scavengers of hydrogen peroxide and hydroxyl radical, respectively. Neither scavenger affected the viability of the E. coli cells [8]. When catalase was added to this system, the viable cell count barely changed. However, addition of benzoate effectively suppressed the bacteri-

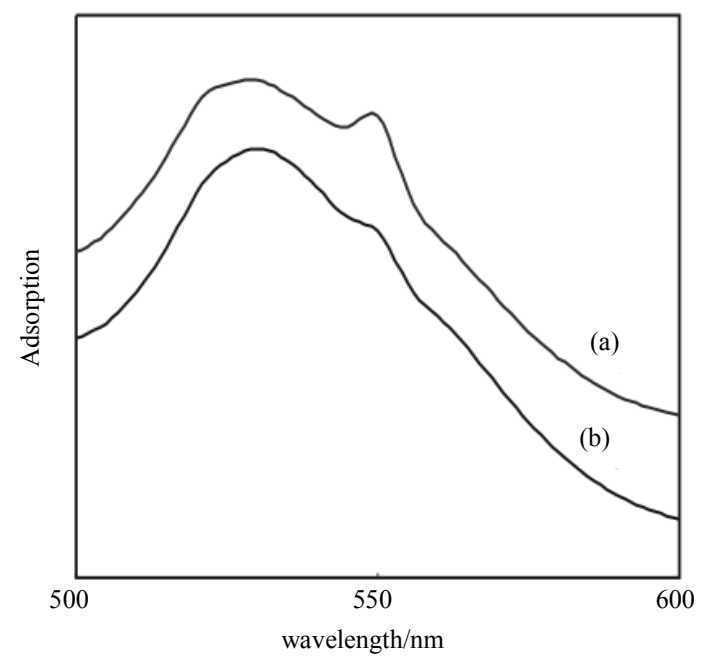

Figure 3. UV/VIS spectra of the solution containing cytochrome c when voltage was applied to the system via the silver electrode; a) The applied voltage was swept between 0 and $0.7 \mathrm{~V}$; b) No voltage was applied.

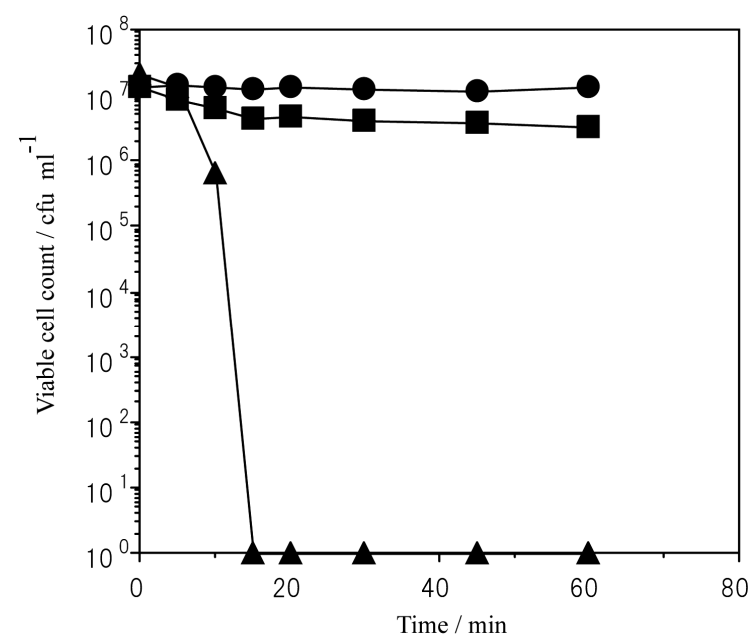

Figure 4. Effect of catalase on the bactericidal activity of the silver electrode; $\square$ : catalase was added to the bacterial suspension at sweeping the applied voltage between 0 and $0.7 \mathrm{~V} ; \Delta$ : no catalase was added to the bacterial suspension as the sweeping voltage ( 0 and $0.7 \mathrm{~V}$ ) was applied to the system; : catalase was added to the bacterial suspension and no voltage was applied.

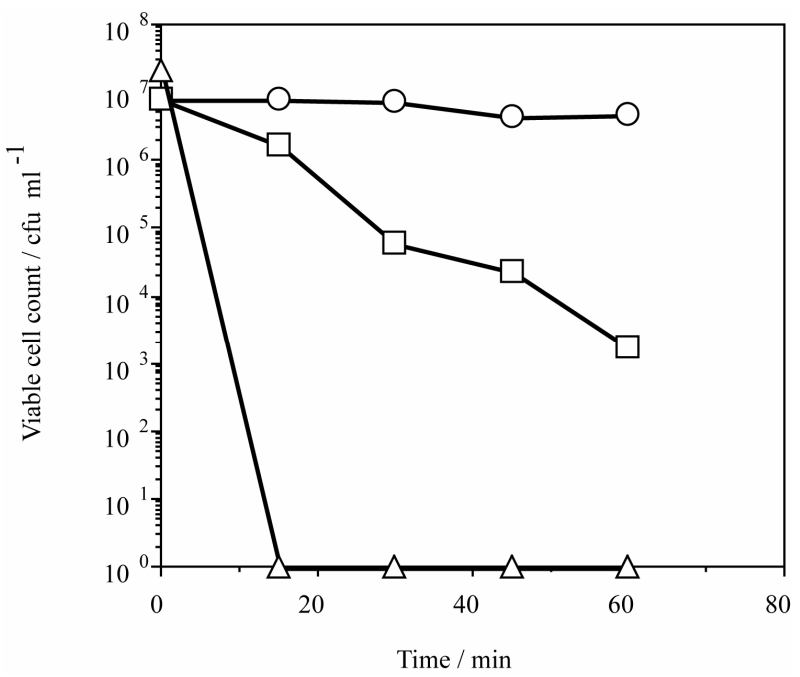

Figure 5. Effect of benzoate on the bactericidal activity of the silver electrode; $\square$ : benzoate was added to the bacterial suspension at sweeping the applied voltage between 0 and $0.7 \mathrm{~V} ; \triangle$ : no benzoate was added to the bacterial suspension as the sweeping voltage $(0$ and $0.7 \mathrm{~V})$ was applied to the system; $O$ : benzoate was added to the bacterial suspension and no voltage was applied.

cidal activity of Ag-Z. These results indicated that the silver redox cycle activated the dissolved dioxygen to form a reactive oxygen species.

In summary, the results obtained in this study indicated that the mode of action of the bactericidal activity of $\mathrm{Ag}-\mathrm{Z}$ was as follows:

1) silver ion in zeolite was reduced to silver metal $\left(\mathrm{Ag}^{+}<\longrightarrow \mathrm{Ag}^{0}\right)$ by light irradiation

2) a redox reaction, specifically the oxidation of silver $\left(\mathrm{Ag}^{0} \longleftrightarrow \longrightarrow \mathrm{Ag}^{+}\right)$and the reduction of dissolved dioxygen proceeded.

3) reduced oxygen species, such as the super oxide anion, hydrogen peroxide, and hydroxyl radical, attacks E. coli, which then lose the ability to grow.

The redox cycle of silver might proceed at a much higher rate in $\mathrm{Ag}-\mathrm{Z}$ than the electrochemical control condition $\left(20 \mathrm{sec} \cdot \mathrm{V}^{-1}\right)$. This might increase the antibacterial activity of Ag-Z.

\section{REFERENCES}

[1] R. M. Slawson, H. Lee and J. T. Trevors, "Bacterial Interactions with Silver," Biometals, Vol. 3, No. 3-4, 1990, pp. 151-154. doi:10.1007/BF01140573

[2] J. R. Furr, A. D. Russell, T. D. Turner and A. Andrews, "Antibacterial Activity of Actisorb Plus, Actisorb and Silver Nitrate," Journal of Hospital Infection, Vol. 27, No. 3, 1994, pp. 201-208. doi:10.1016/0195-6701(94)90128-7

[3] R. J. C.McLean, A. A. Hussain, P. J. Vincent, D. J. Hughes and T. J. N.Smith, "Antibacterial Activity of Multilayer Silver-Copper Surface Films on Catheter Ma- 
terial," Canadian Journal of Microbiology, Vol. 39, No. 9, 1993, pp. 895-899. doi:10.1139/m93-134

[4] G. L. McHugh, R. C. Moellering, C. C. Hopkins and M. N. Swartz, "Salmonella typhimurium Resistant to Silver Nitrate, Chloramphenicol, and Ampicillin," Lancet, Vol. 1, No. 7901, 1975, pp. 235-240. doi:10.1016/S0140-6736(75)91138-1

[5] A. Mandal, V. Meda, W. J. Zhang, K. M. Farhan and A. Gnanamani, "Synthesis, Characterization and Comparison of Antimicrobial Activity of PEG/TritonX-100 Capped Silver Nanoparticles on Collagen Scaffold," Colloids and Surfaces, B: Biointerface, Vol. 90, 2012, pp. 191-196. doi:10.1016/j.colsurfb.2011.10.021

[6] A. Banu, V. Rathod and E. Ranganath, "Silver Nanoparticle Production by Rhizopus stolonifer and Its Antibacterial Activity against Extended Spectrum $\beta$-Lactamase Producing (ESBL) Strains of Enterobacteriaceae," Mate- rials Research Bulletin, Vol. 46, No. 9, 2011, pp. 14171423. doi:10.1016/j.materresbull.2011.05.008

[7] I. Yu and B. Kelman, "Health and Environmental Impact of Silver Nanomaterials," Nanomaterials for the Life Sciences, Vol. 1, 2009, pp. 225-234. doi:10.1002/9783527610419.ntls0128

[8] Y. Inoue, M. Hoshino, H. Takahashi, T. Noguchi, T. Murata, Y. Kanzaki, H. Hamashima and M. Sasatsu, "Bactericidal Activity of Ag-Zeolite Mediated by Reactive Oxygen Species under Aerated Conditions," Journal of Inorganic Biochemistry, Vol. 92, No. 1, 2002, pp. 37-42. doi:10.1016/S0162-0134(02)00489-0

[9] Y. Inoue, M. Kogure, K. Matsumoto, H. Hamashima, M. Tsukada, K. Endo and T. Tanaka, "Light Irradiation Is a Factor in the Bactericidal Activity of Silver-Loaded Zeolite," Chemical \& Pharmaceutical Bulletin, Vol. 56, No. 5, 2008, pp. 692-694. doi:10.1248/cpb.56.692 